\title{
RISIKO ERGONOMI PENYAKIT AKIBAT KERJA PADA PERAWAT GIGI SHINTA CRISTINA SITORUS
}

\author{
Shintacristina13@gmail.com
}

LATAR BELAKANG :

Dalam kehidupan manusia selalu mengadakan berbagai macam aktifitas. Salah satu aktivitas yang rutin dilakukan setiap orang adalah bekerja. Bekerja dapat diartikan sebagai kegiatan manusia dalam melaksanakan suatu tugas yang diakhiri dengan buah karya yang dapat dinikmati oleh manusia yang bersangkutan1. Apapun profesi yang dipilih, bekerja bagi setiap orang selalu dilakukan dalam rangka memenuhi kebutuhan sehari-hari, mulai dari pekerjaan yang berisiko rendah hingga pekerjaan yang berisiko tinggi. Salah satu profesi yang diakui secara resmi di Indonesia adalah perawat gigi. Perawat gigi adalah setiap orang yang telah lulus pendidikan perawat gigi sesuai ketentuan peraturan perundangan-undangan. Perawat gigi memiliki kewenangan untuk menyelenggarakan pekerjaan keperawatan gigi sesuai dengan bidang keahlian yang dimiliki.

Sebagai salah satu jenis tenaga kesehatan, profesi perawat gigi tidak lepas dari berbagai faktor risiko yang memungkinkan terjadinya penyakit yang diakibatkan maupun yang berhubungan dengan pekerjaan yang menimbulkan bahaya terhadap kesehatan kerja (Health Hazard) maupun bahaya keselamatan kerja (Safety Hazard) yang dapat berakibat terjadinya kecelakaan yang dapat menyebabkan kecacatan atau kematian 3. Pencegahan berbagai risiko tersebut harus dilakukan oleh semua pihak dengan cara penyesuaian antara pekerja, proses kerja dan lingkungan kerja.

Ergonomi adalah ilmu yang mempelajari perilaku manusia dalam kaitannya dengan pekerjaan mereka. Sasaran penelitian ergonomi adalah manusia pada saat bekerja dalam lingkungan. Secara singkat dapat dikatakan bahwa ergonomi adalah penyesuaian tugas pekerjaan dengan kondisi tubuh manusia yang ditujukan untuk menurunkan stress yang akan dihadapi. Upayanya antara lain berupa penyesuaian ukuran tempat kerja dengan dimensi tubuh agar tidak melelahkan, pengaturan suhu, cahaya dan kelembaban sesuai dengan kebutuhan tubuh manusia. Bahaya ergonomi merupakan salah satu potensi bahaya dalam K3 yang kurang menjadi perhatian dalam suatu tempat kerja. Padahal bahaya ergonomi dapat menimbulkan kerugian di tempat kerja, dimana bahaya ergonomi dapat mengakibatkan produktivitas dan kualitas pekerja menurun serta dapat menimbulkan penyakit akibat kerja.

Metode : Metode yang digunakan ialah teknik pengumpulan data atau informasi dengan melakukan analisis, eksplorasi, kajian bebas (literatur review) yang relevan, yang berfokus membahas ergonomic dalam dunia bekerja terutama dalam dunia kesehatan, yang mana posisi ergonomis sangat diperlukan dalam setiap tindakan keperawatan untuk mencegah adanya cedara atau kelelahan fisik pada perawat .Referensi yang digunakan adalah jurnal dan artikel ilmiah pada penerbitan 8 tahun terakhir. Dalam mencari referensinya, menggunakan kata kunci ergonomi ,keselamatan, kesehatan, keperawatan.

Hasil : Penyakit akibat kerja timbul dikarenakan adanya ketidakseimbangan antara tugas,organisasi dan lingkungan banyak menggunakan gerakan membungkuk dan memutar tubuh, khususnya di sekitar tulang bawah. Mengangkat benda berat dan mentransfer pasien merupakan faktor risiko terbesar terkena low back pain. Aktivitas kerja di rumah sakit cukup berat dan mempunyai potensi timbulnya gangguan kesehatan bagi pekerja. Pekerjaan perawat banyak berhubungan langsung dengan pasien. Pada pelayanan kesehatan pajanan ergonomi dapat dialami oleh perawat. Sikap kerja tidak ergonomis yaitu sikap kerja yang menyebabkan posisim bagian-bagian tubuh bergerak menjauhi posisi alamiah, misalnya tangan terangkat, punggung terlalu membungkuk, kepala terangkat, dan sebagainya. Semakin jauh dari pusat gravitasi, maka semakin tinggi risiko terjadinya keluhan. Rapid Upper Limb Assesment (RULA) merupakan suatu metode penelitian dengan skor menggunakan target postur tubuh untuk mengestimasi terjadinya risiko gangguan skeletal, khususnya pada anggota tubuh bagian atas.

\section{Pembahasan : Penyakit Akibat Kerja (PAK)}

1. Definisi Penyakit Akibat Kerja

Penyakit akibat kerja adalah penyakit yang ditimbulkan oleh atau didapat pada waktu melakukan pekerjaan. Penyakit akibat kerja atau yang lebih dikenal sebagai occupational diseases adalah penyakit yang disebabkan oleh faktor-faktor pekerjaan atau didapat pada waktu melakukan pekerjaan . Faktor Lingkungan kerja sangat berpengaruh dan berperan sebagai penyebab timbulnya Penyakit Akibat Kerja

2. Faktor Penyebab Penyakit Akibat Kerja

Faktor-fakor penyebab penyakit akibat kerja dapat dibedakan sebagai berikut:

a. Faktor Fisik, yang meliputi:

1) Suara tinggi/bising yang dapat menyebabkan ketulian.

2) Temperatur/suhu tinggi yang dapat menyebabkan Hyperpireksi, Milliaria, heat Cramp, Heat Exhaustion, Heart Stroke.

3) Radiasi sinar elektromagnetik, pada mata infra merah dapat menyebabkan katarak, ultraviolet menyebabkan konjungtivitis, radioaktif/ alfa/ beta/

gama/ X menyebabkan gangguan terhadap sel tubuh manusia.

4) Tekanan udara tinggi yang dapat menyebabkan Coison Disease.

5) Getaran/vibration yang dapat menyebabkan Reynaud's Disease, Gangguan proses metabolisme, Polineurutis. b. Faktor Kimia

1) Berasal dari bahan baku, bahan tambahan, hasil antara, hasil samping, hasil (produk), sisa produksi atau bahan buangan yang dapat berbentuk zat padat, cair, gas, uap maupun partikel. Materi ini masuk ke tubuh dapat melalui saluran pernafasan, saluran pencernaan, kulit dan mukosa. 2) Efek terhadap tubuh dapat menyebabkan iritasi, alergi, korosif, Asphyxia, keracunan sistemik, kanker, kerusakan/kelainan janin, pneumoconiosis, efek bius (narkose) dan pengaruh genetik. 
c. Faktor biologi yang dapat berasal dari virus, bakteri, parasit, jamur, serangga, binatang buas, dan lain-lain.

\section{d. Faktor Ergonomi/Fisiologi}

1) Penyebabnya adalah cara kerja, posisi kerja, alat kerja, lingkungan kerja yang salah dan kontruksi salah.

2) Efek terhadap tubuh yaitu dapat menyebabkan kelelahan fisik, nyeri otot, deformitas tulang, perubahan bentuk dan dislokasi. e. Faktor Mental/Psikologi

1) Penyebabnya yaitu suasana kerja monoton dan tidak nyaman, hubungan kerja kurang baik, upah kerja kurang, terpencil, atau tak sesuai bakat yang mengakibatkan stress.

\section{Ergonomi}

Ergonomi atau ergonomics (Bahasa Inggris) menurut Sritomo Wignjosoebroto (1995)7 berasal dari kata yunani yaitu Ergo yang berarti kerja dan Nomos yang berarti hukum. Ergonomi dimaksudkan sebagai disiplin keilmuan yang mempelajari manusia dalam kaitannya dengan pekerjaan. Disiplin ergonomi secara khusus akan mempelajari keterbatasan dari kemampuan manusia dalam berinteraksi dengan teknologi dan produkproduk buatannya. Disiplin ini berangkat dari kenyataan bahwa manusia memiliki batas-batas kemampuan baik jangka pendek maupun jangka panjang pada saat berhadapan dengan keadaan lingkungan sistem kerjanya yang berupa perangkat keras/hardware (mesin, peralatan kerja dll) dan/atau perangkat lunak/software (metode kerja, sistem dan prosedur, dll).

Dalam perkembangan selanjutnya, ergonomi dikelompokkan atas empat bidang penyelidikan yaitu:

a. Penyelidikan tentang tampilan (display). Tampilan (display) adalah suatu perangkat antara (interface) yang menyajikan informasi tentang keadaan lingkungan,dan mengkomunikasikannya pada manusia dalam bentuk tanda-tanda, angka, lambang dansebagainya,

b. Penyelidikan tentang kekuatan fisik manusia. Dalam hal ini diselidiki tentang aktivitas-aktivitas manusia ketika bekerja, dan kemudian dipelajari cara mengukur aktivitas-aktivitas tersebut

c. Penyelidikan tentang ukuran tempat kerja. Penyelidikan ini bertujuan untuk mendapatkan rancangan tempat kerja yang sesuai dengan ukuran(dimensi) tubuh manusia, agar diperoleh tempat kerja yang baik, yang sesuai dengan kemampuan dan keterbatasan manusia. d. Penyelidikan tentang lingkungan kerja. Penyelidikan ini meliputi kondisi lingkungan fisik tempat kerja dan fasilitas kerja seperti pengaturan cahaya, kebisingan suara, temperatur, getaran dll. yang dianggap dapat mempengaruhi tingkah laku manusia .

\section{Risiko Ergonomi Penyakit Akibat Kerja pada Perawat Gigi}

Prevalensi gejala muskuloskeletal berkisar 40-80\%. Hal ini menunjukkan gejala muskuloskeletal relatif tinggi pada pekerja di Indonesia Ergonomi menjadi pilar kesehatan dan menjadi salah satu indikator kesejahteraan. Menurut Meily (2013), perbaikan ergonomic perlu dilakukan sebagai salah satu upaya pencegahan terhadap penyakit CTDs (Cumulative Trauma Disorders) akibat factor risiko kerja postur janggal, beban, frekuensi dan durasi yang bersumber dari pekerjaan, seperti nyeri tengkuk, nyeri pinggang bawah atau low back pain, rasa baal pada jari telunjuk, jari tengah dan jari manis yang disertai nyeri terbakar pada malam hari, kekakuan, lemah dan nyeri saat tangan digunakan dan dikenal dengan nama Carpal Tunnel Syndrome.

\section{Musculoskeletal Disorders (MSDs) a. Definisi}

Muskuloskeletal disorder adalah gangguan pada bagian otot skeletal yang disebabkan oleh karena otot menerima beban statis secara berulang dan terus menerus dalam jangka waktu yang lama dan akan menyebabkan keluhan berupa kerusakan pada sendi, ligamen dan tendon.

Secara garis besar keluhan otot dapat dikelompokkan menjadi 2, yaitu:

1) Keluhan sementara (reversible) yaitu keluhan otot yang terjadi pada saat otot menerima beban statis namun demikian keluhan tersebut akan segera hilang bila pembebanan dihentikan.

2) Keluhan menetap (persistent) yaitu keluhan otot yang bersifat menetap. Walaupun pembebanan kerja dihentikan, namun rasa sakit pada otot masih terus berlanjut. Studi tentang MSDs pada berbagai jenis industri telah banyak dilakukan dan hasil studi menunjukkan bahwa bagian otot yang sering dikeluhkan adalah otot rangka (skeletal) yang meliputi otot leher, bahu, lengan, tangan, jari, punggung, pinggang dan otot-otot bagian bawah.

\section{b. Faktor Penyebab}

faktor penyebab musculoskeletal disorders antara lain9:

1) Faktor Penyebab Primer

a) Peregangan otot yang berlebihan (overexxertion). Peregangan otot yang berlebihan pada umumnya dikeluhkan oleh pekerja dimana aktivitas kerjanya menuntut pengerahan yang besar, seperti aktivitas mengangkat, mendorong, menarik, menahan beban yang berat.

b) Aktivitas berulang adalah pekerjaan yang dilakukan secara terus menerus. Seperti mencangkul, membelah kayu, angkat-angkut dan sebagainya.

c) Sikap kerja tidak alamiah adalah sikap kerja yang menyebabkan posisi bagian-bagian tubuh bergerak menjauhi posisi ilmiah, misalnya pergerakan tangan terangkat, punggung terlalu membungkuk dan sebagainya.

2) Fator penyebab sekunder

a) Tekanan yaitu terjadinya tekanan langsung pada jaringan otot yang lunak.

b) Getaran dengan frekuensi yang tinggi akan menyebabkan kontraksi otot bertambah. Kontraksi statis ini menyebabkan peredaran darah tidak lancar, penimbunan asam laktat meningkat dan akhirnya timbul rasa nyeri otot.

c) Mikroklimat yaitu paparan suhu dingin yang berlebihan dapat menurunkan kelincahan, kepekaan dan kekuatan pekerja sehingga pergerakan pekerja menjadi lamban, sulit bergerak disertai dengan menurunnya kekuatan otot.

\section{3) Penyebab Kombinasi}

a) Umur yaitu prevalensi sebagian besar gangguan tersebut meningkat dengan usia.

b) Jenis kelamin yaitu prevalensi sebagian besar gangguan tersebut meningkat dan lebih menonjol pada wanita dibandingkan pria (3:1).

c) Kebiasaan merokok yaitu semakin lama dan semakin tinggi tingkat frekuensi merokok, semakin tinggi pula keluhan otot yang dirasakan.

d) Kesegaran jasmani yaitu tingkat kesegaran tubuh yang rendah akan mempertinggi risiko terjadinya keluhan otot.

e) Kekuatan fisik.

f) Ukuran tubuh (antropometri)

C . Mengatasi Musculoskeletal Disorders

Langkah-langkah dalam mengatasi MSDs antara lain:

1) Rekayasa Teknik

a) Eliminasi, yaitu dengan menghilangkan sumber bahaya yang ada.

b) Substitusi 
yaitu mengganti alat atau bahan lama dengan alat atau bahan baru yang aman, menyempurnakan proses produksi dan menyempurnakan prosedur penggunaan peralatan.

c) Partisi, yaitu pemisahan sumber bahaya dengan pekerja.

d) Ventilasi, yaitu dengan menambah ventilasi untuk mengurasi risiko sakit.

\section{2) Rekayasa Manajemen}

a) Pendidikan dan pelatihan.

b) Pengaturan waktu kerja dan istirahat seimbang.

c) Pengawasan yang intensif.

\section{Low Back Pain (LBP) atau Nyeri Punggung Bagian Bawah (NPB)}

a. Definisi

Nyeri punggung bawah adalah nyeri pada daerah punggung bawah yang berkaitan dengan masalah vertebra lumbar, diskus intervertebralis, ligamentum di antara tulang belakang dengan diskus, medula spinalis, dan saraf otot punggung bawah, organ internal pada pelvis dan abdomen atau kulit yang menutupi area lumbar .

Sedangkan nyeri punggung bawah mengacu pada nyeri di daerah lumbosaral tulang belakang meliputi jarak dari vertebra lumbar pertama ke tulang vertebra sacral pertama. Ini adalah area tulang belakang dimana bentuk kurva lordotic. Yang paling sering menyebabkan nyeri pinggang adalah di segmen lumbal 4(empat) dan 5 (lima).

Mengenai nyeri punggung bawah pada pekerja rumah sakit Tshwane di Afrika Selatan menyatakan bahwa prevalensi nyeri punggung bawah di pekerja rumah sakit adalah $47 \%$. Faktor yang berpengaruh antara lain adalah jenis kelamin wanita dan keikutsertaan pekerja dalam aktivitas fisik12. Tidak ada pengaruh dari penyakit penyerta dalam risiko nyeri punggung bawah. Sebanyak 31,25\% perawat RSUD Purbalingga melakukan sikap dan posisi kerja yang berisiko cedera muskuloskeletal. Perawat yang mengalami nyeri punggung bawah sebanyak 18,75 \%. Terdapat hubungan antara usia dan masa kerja dengan nyeri punggung bawah 14.

b. Faktor Risiko

1) Umur

Nyeri pinggang merupakan keluhan yang berkaitan erat dengan umur. Secara teori, nyeri pinggang atau nyeri punggung bawah dapat dialami oleh siapa saja, pada umur berapa saja. Namun demikian keluhan ini jarang dijumpai pada kelompok umur 0-0 tahun, hal ini mungkin berhubungan dengan beberapa faktor etiologik tertentu yag lebih sering dijumpai pada umur yang lebih tua. Biasanya nyeri ini mulai dirasakan pada mereka yang berumur dekade kedua dan insiden tertinggi dijumpai pada dekade kelima. Bahkan keluhan nyeri pinggang ini semakin lama semakin meningkat hingga umur sekitar 55 tahun.

2) Jenis Kelamin

Laki-laki dan perempuan memiliki risiko yang sama terhadap keluhan nyeri pinggang sampai umur 60 tahun, namun pada kenyataannya jenis kelamin seseorang dapat mempengaruhi timbulnya keluhan nyeri pinggang, karena pada wanita keluhan ini lebih sering terjadi misalnya pada saat mengalami siklus menstruasi, selain itu proses menopause juga dapat menyebabkan kepadatan tulang berkurang akibat penurunan hormon estrogen sehingga memungkinkan terjadinya nyeri pinggang.

\section{3) Indeks Masa Tubuh (IMT)}

Pada orang yang memiliki berat badan yang berlebih risiko timbulnya nyeri pinggang lebih besar, karena beban pada sendi penumpu berat badan akan meningkat, sehingga dapat memungkinkan terjadinya nyeri pinggang. Tinggi badan berkaitan dengan panjangnya sumbu tubuh sebagai lengan beban anterior maupun lengan posterior untuk mengangkat beban tubuh.

4) Pekerjaan

Keluhan nyeri ini juga berkaitan erat dengan aktivitas mengangkat beban berat, sehingga riwayat pekerjaan sangat diperlukan dalam penelusuran penyebab serta penanggulangan keluhan ini. Pada pekerjaan tertentu, misalnya seorang kuli pasar yang biasanya memikul beban di pundaknya setiap hari. Mengangkat beban berat lebih dari $25 \mathrm{~kg}$ sehari akan memperbesar risiko timbulnya keluhan nyeri pinggang.

\section{5) Aktivitas / Olahraga}

Sikap tubuh yang salah merupakan penyebab nyeri pinggang yang sering tidak disadari oleh penderitanya. Terutama sikap tubuh yang menjadi kebiasaan. Kebiasaan seseorang, seperti duduk, berdiri, tidur, mengangkat beban pada posisi yang salah dapat menimbulkan nyeri pinggang, misalnya, pada pekerja kantoran yang terbiasa duduk dengan posisi punggung yang tidak tertopang pada kursi, atau seorang mahasiswa yang seringkali membungkukkan punggungnya pada waktu menulis. Posisi berdiri yang salah yaitu berdiri dengan membungkuk at au menekuk ke muka. Posisi tidur yang salah seperti tidur pada kasur yang tidak menopang spinal. Kasur yang diletakkan di atas lantai lebih baik daripada tempat tidur yang bagian tengahnya lentur. Posisi mengangkat beban dari posisi berdiri langsung membungkuk mengambil beban merupakan posisi yang salah, seharusnya beban tersebut diangkat setelah jongkok terlebih dahulu. Selain sikap tubuh yang salah yang seringkali menjadi kebiasaan, beberapa aktivitas berat seperti melakukan aktivitas dengan posisi berdiri lebih dari 1 jam dalam sehari, melakukan aktivitas dengan posisi duduk yang monoton lebih dari 2 jam dalam sehari, naik turun anak tangga lebih dari 10 anak tangga dalam sehari, berjalan lebih dari 3,2 $\mathrm{km}$ dalam sehari dapat pula meningkatkan risiko timbulnya nyeri pinggan15.

6) Posisi Tubuh

Posisi lumbar yang berisiko menyebabkan terjadinya nyeri punggung bawah ialah fleksi ke depan, rotasi, dan mengangkat beban yang berat dengan tangan yang terbentang. Beban aksial pada jangka pendek ditahan oleh serat kolagen annular di diskus. Beban aksial yang lebih lama akan memberi tekanan pada fibrosis annular dan meningkatkan tekanan pada lempeng ujung. Jika annulus dan lempeng ujung utuh, maka beban dapat ditahan. Akan tetapi, daya kompresi dari otot dan beban muatan dapat meingkatkan tekanan intradiskus yang melebihi kekuatan annulus, sehingga menyebabkan robeknya annulus dan gangguan diskus 15.

\section{Hernia Nucleus Pulposus (HNP)}

\section{a. Definisi}

Hernia Nucelus Pulposus (HNP) adalah suatu nyeri yang disebabkan oleh proses patologik dikolumna vertebralis pada diskus intervertebralis (diskogenik). Herniasi diskus intervertebralis ke segala arah dapat terjadi akibat trauma atau stress fisik. Herniasi ke arah superior atau inferior melalui lempeng kartilago masuk ke dalam korpus vertebrata dinamakan sebagai nodul schmorl (biasanya dijumpai secara insidentil pada gambaran radiologist atau otopsi). 
b. Klasifikasi

HNP terbagi atas:

1) HNP sentral. HNP sentral akan menimbulkan paraparesis flasid, parestesia, dan retensi urine.

2) HNP lateral. Rasa nyeri terletak pada punggung bawah, di tengah-tengah antara pantat dan betis, belakang tumit dan telapak kaki. Ditempat itu juga akan terasa nyeri tekan. Kekuatan ekstensi jari ke V kaki berkurang dan refleks achiler negatif. Pada HNP lateral L 4-5 rasa nyeri dan tekan didapatkan di punggung bawah, bagian lateral pantat, tungkai bawah bagian lateral, dan di dorsum pedis. Kekuatan ekstensi ibu jari kaki berkurang dan refleks patella negatif.

\section{c. Faktor Risiko}

Beberapa faktor yang dapat menyebabkan nyeri pada tulang belakang, antara lain:

1) Faktor Fisik/ Pekerjaan Mengangkat dan membawa beban dan membungkuk serta memutar menunjukkan adanya keterkaitan dengan cidera tulang belakang. Kebanyakan pekerjaan yang terdiri dari kombinasi mengangkat dan pergerakan lainnya seperti mengangkat dengan memutar memiliki risiko yang besar.. Ada bukti yang kuat untuk terjadinya cidera pada tulang belakang dengan pekerjaan yang mengangkat dan pergerakan yang memaksa. Mereka juga menyatakan bahwa ada bukti yang terkait dengan postur janggal, seperti pekerjaan fisik yang berat yang dikaitkan dengan cidera pada tulang belakang. Ini juga merupakan temuan bahwa perawat dengan pekerjaan melayani yang lebih lama memiliki risiko yang lebih tinggi.

Faktor-faktor yang memberikan sumbangan terbesar bagi terjadinya cidera pada perawat adalah:

a) Tindakan manual handling.

b) Postur janggal yang menimbulkan kekakuan otot.

c) Tergelincir, tersandung dan terjatuh.

d) Mendorong, menarik trolley.

e) Merapihkan dan membersihkan tempat tidur pasien.

f) Penanganan bahan linen dan apron.

2) Faktor Psikososial dan Lingkungan Kerja

Beberapa studi menunjukkan bahwa cidera tulang belakangterkait dengan lingkungan psikososial yang buruk dimana yang lainnya tidak ditemukan hubungan. Pengkajian pada pengaruh faktor psikososial pada nyeri tulang belakang dilaporkan sulit, seperti pekerjaan dengan physical demand yang tinggi yang biasanya termasuk lingkungan sosial yang buruk. Dari studi epidemiologi terkait dengan perubahan generatif ke faktor mekanis telah dikaburkan oleh kenyataan bahwa ada banyak faktor yang dapat menyebabkan terjadinya nyeri pada tulang belakang.

3) Faktor Individu dan Gaya Hidup (life style)

a) Umur. Keberadaan nyeri pada tulang belakang meningkat seiring dengan bertambahnya usia sekitar umur 50-60 tahun, walaupun itu terlihat akan dipatahkan.. Dengan kata lain, cidera pada tulang belakang karena kecelakaan telah ditunjukkan terkait dengan umur, mengikuti bentuk kurva

b) Jenis kelamin. Beberapa studi menunjukkan bahwa prevalensi dari cidera tulang belakang lebih tinggi pada pria daripada wanita, dimana cidera muskuloskeletal pada ekstremitas atas lebih sering pada wanita

c) Overweight. Pada beberapa studi, kelebihan berat badan dapat meningkatkan risiko terjadinya cidera tulang belakang. Studi lainnya juga yang meneliti hubungan antara berat badan dan cidera tulang belakang tidak menemukan hubungan.Efek dari kelebihan berat badan mungkin hanya substansial untuk kebanyakan mereka yang kelebihan berat badan.

d) Merokok. Merokok diindikasikan sebagai faktor risiko untuk terjadinya cidera pada tulang belakang pada beberapa studi. Keterkaitan antara merokok dengan batuk telah ditemukan, yang dapat meningkatkan tekanan intradiscal yang membawa pada pembengkakan diskus dan hernia. Penjelasan lainnya adalah efek dari nikotin yang mengurangi aliran darah pada vertebral dan merusak metabolism diskus dan membuat diskus lebih sensitive pada stress fisik

penutup : Penyakit akibat kerja timbul akibat adanya ketidakseimbangan antara tugas dan kemampuan pekerja. Jika pengetahuan ergonomi, sikap kerja, dan masa kerja dikontrol dengan baik, maka risiko keluhan gangguan dapat dikurangi. Pengetahua keyakinan, dan sikap berperan pada kecelakaan kerja. Perawat harus mendapatkan pelatihan teknik kerja yang baik dalam mengatasi stres dan tekanan psikologis untuk mengurangi masalah atau cedera terkait pekerjaan. 
DAFTAR PUSTAKA :

1.Binarfi ka Maghfi roh Nuryaningtyas ,Tri Martiana.(2014).Analisis Tingkat Risiko Muskuluskletas Disorders (MSDs) Dengan The Rapid Upper Limbs Assessment (RULA) Dan Karakteristik Individu Terhadap Keluhan MSDs. The Indonesian Journal of Occupational Safety and Health .3(2).

2. Departemen Kesehatan RI, 2007, Occupational Health - Industrial Health, Jakarta: Kementrian Kesehatan

3. Diki Bima Prasetio,dkk .(2015).Risiko Bahaya Ergonomi Petugas Kebersihan Outsourcing Di Rumah Sakit Umum Daerah Sleman. Jurnal Kesehatan Masyarakat Indonesia,10(1).

4.International Labour Organization, 2013, Keselamatan dan Kesehatan Kerja - Sarana untuk Produktivitas (Pedoman pelatihan untuk manajer dan pekerja - Modul Lima), Jakarta: Score

5. Ishana Balaputra , Adi Heru Sutomo. (2017). Pengetahuan ergonomi dan postur kerja perawat pada perawatan luka dengan gangguan muskuloskeletal di dr. H. Koesnadi Bondowoso BKM Journal of Community Medicine and Public Health.33(9).

6. Menteri Kesehatan Republik Indonesia, 2012, Peraturan Menteri Kesehatan Republik Indonesia Nomor 58 Tahun 2012 Tentang Penyelenggaraan Pekerjaan Perawat Gigi, Jakarta: Kementerian Kesehatan

7. Moch. Aspihan, Junaiti Sahar,Henny Permatasari. Ergonomik Partisipatif Berjenjang Sebagai Bentuk Intervensi Keperawatan Komunitas Pada Kelompok Pekerja Dengan Risiko Gangguan Muskuloskeletal Di Pt X The Levelling Participatory Ergonomic as community health nursing intervention for worker population with risk of musculoskeletal disorder.Unissula Press.

8. Moeliono F. Etiologi. 1993. Diagnosis dan Terapi Sindroma Terowongan Karpal (S.T.K.) atau (Carpal Tunnel Syndrome/CTS). Neurona; 10 : $16-27$.

9. Kilbom Å \& Messing K. 1998. Work-related musculoskeleta disorders. In: Kilbom Å, Messing K \& Bildt Torbjörnsson C eds. Women's health at work. , Solna: National Institute for Working Life.

10. Simamora, R. H. (2017). A strengthening of role of health cadres in BTA-Positive Tuberculosis (TB) case invention through education with module development and video approaches in Medan Padang bulanComunity Health Center, North Sumatera Indonesia. International Journal of Applied Engineering Research, 12(20), 10026-10035.

11. Simamora, R. H., \&Saragih, E. (2019). Penyuluhankesehatanterhadapmasyarakat: Perawatanpenderitaasamuratdengan media audiovisual. JPPM (JurnalPendidikandanPemberdayaanMasyarakat), 6(1), 24-31.

12. Troup JDG. 1987. The handling of patient. London: Royal College of Nursing. 